\title{
Solving Linear Programming Models by Spreadsheet Software Packages
}

\author{
Zolfa Abdul FatTaH Shalaby \\ Assistant Professor \\ Department of Business Administration \\ Faculty of Economics and Administration \\ King Abdul-Aziz University, Jeddah, Saudi Arabia
}

(Received 24.10.1420H, and Accepted 24.2.1421H)

\begin{abstract}
This paper focuses upon how it is possible to create optimal solution to the problem of production planning through spreadsheet software packages. This opens new application horizons and new methods of teaching management science. A numerical example is given to show the importance of this new technique.
\end{abstract}

\section{Introduction}

Decision-makers are often faced with the problem of determining optimal allocation of limited resources. The problem is to determine the best combination of activity levels which does not use more resources than are actually available and at the same time maximize output, revenue, service level, ..., or to minimize costs. These kinds of problems arise for example in production planning, feed stock blending, investment portofolio management and staff scheduling.

For this type of problems LP, perhaps the best known of all management science techniques, often provide the optimum solution for a number of variables within a set of constraints.

While LP is taught on most undergraduate and Postgraduate management courses, it is rarely used by the practicing manager. The main reason for this is that LP software is often expensive, difficult to use and time consuming to learn (Caine, D. J. and Parker, B.J., 1996[4], pp.46). 
In this article, we argue that this must be changed by applying spreadsheet packages, in particular the solver which is a function in Microsoft Excel. It affords the user a remarkably powerful tool for solving linear and non-linear optimization problems and provides additional information to support decision making.

The new generation of optimization tools incorporated within spreadsheet packages cannot only improve decision making efficiency by producing quick and easy to understand solution to this type of problems but can also enhance decision making effectiveness by providing decision makers with additional understanding about the problem and a powerful "what if"? Tool.

\section{Literature review}

Spreadsheet software package in general, and Excel in particular, have been used extensively in managerial decision making. Al Faraj, Taqui N., et al 1990[1], showed that the waiting-line problem can be simulated by the manager within the spreadsheet environment. Caine, D. J. and Parker, B. J., 1996[4], discussed the applying of optimization techniques such as linear programming in managerial decision making using spreadsheet software packages. Winston, Wayne L. and AIbright, S. Christian, 1997 [9], surveyed many applications of spreadsheet software packages in several fields such as: Finance, Human Resources, Marketing and Operation Management.

\section{Linear Programming Model within Spreadsheet}

There are three methods for solving LP problems:

- Firstly, graphical LP, which is limited to only two variables.

- Secondly, manual use of simplex algorithm, which requires a large volume of calculations,

- Finally, the use of software packages which are expensive and difficult to interpret (Caine, D. J. and Parker, B. J., 1996[4], pp.46).

For a practicing decision maker, the power associated with Excel solver or similar spreadsheet functions, now eliminates the weaknesses associated with all of the previous methods. The easiest way to demonstrate this is through the use of an example.

\section{Applied Example}

A small firm produces a variety of chemical based products. In the production process, three raw materials are used to produce two products, a fuel additive and solvent base. The fuel additive is sold to oil companies and used in production of gasoline and related fuels. The solvent base is sold to a variety of chemical firms and is used in both home and industrial cleaning products. The three raw materials are blended to form the fuel additive and solvent base as indicated in the following table:

\begin{tabular}{|l|c|c|c|}
\hline \multicolumn{1}{|c|}{ Product } & Material 1 & Material 2 & Material 3 \\
\hline Fuel additive & 0.4 & Zero & 0.6 \\
Solvent base & 0.5 & 0.2 & 0.3 \\
\hline Amount of available & 20 tons & 5 tons & 21 tons \\
production & & & \\
\hline
\end{tabular}


Let $\mathrm{X}_{1}$ be the number of tons of fuel additive that the firm produces, and $\mathrm{X}_{2}$ be the number of tons of solvent base that the firm produces. Firm's profit contribution for two products $X_{1}, X_{2}$ are $\$ 40$ and $\$ 30$ respectively. The objective function is defined as:

and the constraints are:

$$
\mathrm{Z}=40 \mathrm{X}_{1}+30 \mathrm{X}_{2} \rightarrow \operatorname{Max}
$$

$$
\begin{aligned}
& 0.4 X_{1}+0.5 X_{2} \leq 20 \\
& 0.0 X_{1}+0.2 X_{2} \leq 5 \\
& 0.6 X_{1}+0.3 X_{2} \leq 21 \\
& X_{1} \geq 0, X_{2} \geq 0
\end{aligned}
$$

\section{Solving the example using an electronic spreadsheet model}

1- At first, we must reserve one cell in the spreadsheet for each of the decision variables and one cell for the value of the objective function. We reserved cells B4 and $\mathrm{C} 4$ for the values of the decision variables and A4 for the value of the value of the objective function.

2- The values in cells B3 and C3 are the profit contributions for each of the decision variables. The values in cells E5, E6 and E7 show the quantity of tons of materials I,2 and 3 available.

3- The value of the objective function is the sum of the product of 40 times the number of tons of fuel additive produced and 30 times the number of tons of solvent base produced. So we used the SUMPRODUCT function and enter the formula in cell A4.

$$
\text { = SUMPRODUCT }(\mathrm{B} 3: \mathrm{C} 3 ; \mathrm{B} 4: \mathrm{C} 4)
$$

4- Next, we must enter the formulas which define how the entries in cells D5, D6 and D7 are computed. For example, the formula:

$$
=\text { SUMPRODUCT }(\$ B \$ 4: \$ C \$ 4, \mathrm{~B} 5: \mathrm{C} 5)
$$

\begin{tabular}{|c|c|c|c|c|c|}
\hline & A & B & $\mathrm{C}$ & $\mathrm{D}$ & E \\
\hline 1 & & fuel & Solvent & & \\
\hline 2 & & additive & base & & \\
\hline 3 & optimal value & 40 & 30 & & material \\
\hline 4 & $=$ SUMPRODUCT(B3:C3,B4:C4) & & & optimal value & available \\
\hline 5 & & 0.4 & 0.5 & $=$ SUMPRODUCT $(\$ B \$ 4: \$ C \$ 4, B 5: C 5)$ & 20 \\
\hline 6 & & 0.0 & 0.2 & $=$ SUMPRODUCT $(\$ B \$ 4: \$ C \$ 4, B 6: C 6)$ & 5 \\
\hline 7 & & 0.6 & 0.3 & $=$ SUMPRODUCT $(\$ B \$ 4: \$ C \$ 4, B 7: C 7)$ & 21 \\
\hline
\end{tabular}

shows that the number of tons of material 1 is used, the sum of the product of the value in cell B4 [the number of tons of fuel additive produced) times 0.4 plus the value in cell $\mathrm{C} 4$ [the number of tons of solvent base produced] times 0.5 .

By copying the formula to cells D6 and D7 we obtain the formulas for these cells :

$$
\begin{aligned}
& =\text { SUMPRODUCT }(\$ B \$ 4: \$ C \$ 4, \mathrm{~B} 6: \mathrm{C} 6) \\
& =\text { SUMPRODUCT }(\$ B \$ 4: \$ C \$ 4, \mathrm{~B} 7: \mathrm{C} 7)
\end{aligned}
$$

The spreadsheet of initial solution appears in Fig. (1).

Fig. (1): Spreadsheet of initial solution 
5- To solve the linear program, which we have just defined, we select the solver dialog box from the tool menu. Then we indicate whether we want to solve a maximization or minimization problem and specify the following information about the problem:

1) The target cell, which is the cell in the spreadsheet that will contain the value we want to maximize or minimize,

2) The changing cells or decision variables, and

3) The constraints.

Since the formula in cell A4 represents the total profit contribution, we identify cell A4 as the target cell. Next we define the changing cells as cells B4 and C4. Then, we specify the two non-negativity constraints as:

\section{\$B \$4 : \$C \$4}

Finally we identify the constraints corresponding to the available supplies of three raw materials as:

$$
\text { \$D \$5: \$D \$7 < = \$E \$5: SE \$7 }
$$

Solver dialog box for our example is shown in Fig. (2)

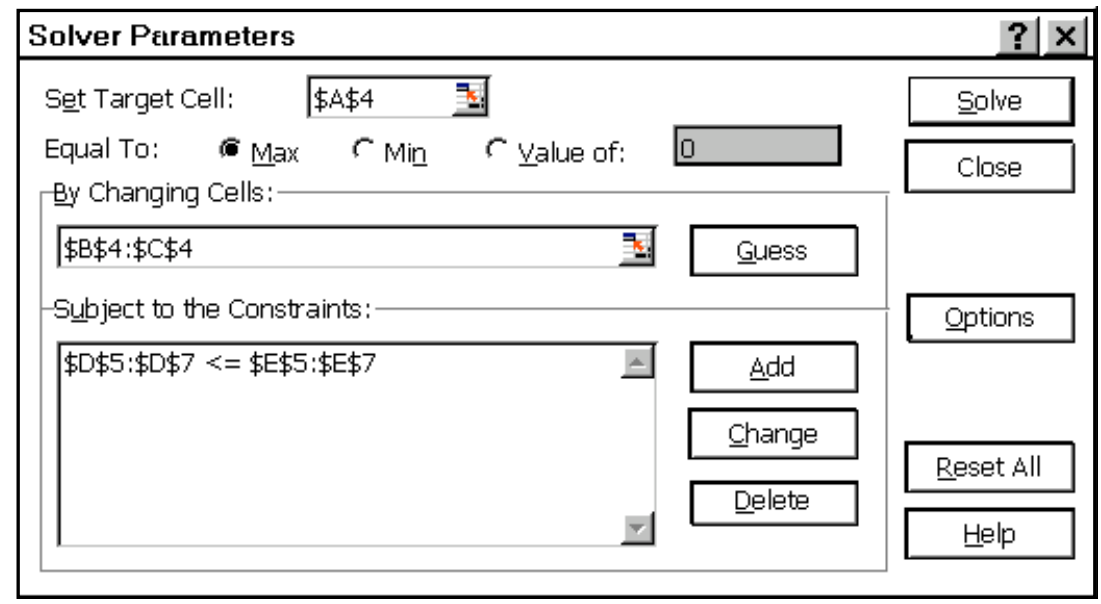

fig. (2). Solver dialog box

After that we select the solve options in the solver dialog box. The spreadsheet results produced by solver are shown in Fig. (3).

\begin{tabular}{|r|r|r|r|r|r|}
\hline & \multicolumn{1}{|c|}{ A } & \multicolumn{1}{c|}{ B } & \multicolumn{1}{c|}{ C } & D & \multicolumn{1}{c|}{ E } \\
\hline 1 & & fuel & \multicolumn{1}{c|}{ Solvent } & & \\
\hline 2 & & additive & \multicolumn{1}{c|}{ base } & & material \\
\hline 3 & optimal value & 40 & 30 & & available \\
\hline 4 & & 25 & 20 & Material used & 20 \\
\hline 5 & & 0.4 & 0.5 & 4 & 5 \\
\hline 6 & & 0.0 & 0.2 & & 21 \\
\hline 7 & & 0.6 & 0.3 & & 21 \\
\hline
\end{tabular}

fig. (3) The spreadsheet results produced by solver 
From the previous table the optimal solution is 25 tons of fuel additive and 20 tons of solvent base, and optimal value of the function is $1600 \$$.

\section{Post 0ptimal Analysis}

In addition to the output information, solver has an option to provide an answer report and sensitivity analysis information.

The answer report gives details of the final solution in a report format and also shows which constraints are binding. These are the constraints which currently limit the solution of the objective function.

The answer report also shows the other possible constraints that do not limit the solution.

The sensitivity report gives a useful information about how sensitive the answers are to change in the data. More important, it indicates what extra contribution is likely to be gained if the binding constraints could be changed and over what range of values this would apply. This provides the answer to many "what if"? questions. "What if"? questions involving changes outside this range can be answered easily by re-running the model. The answer report and sensitivity report are shown in Fig. 4 and Fig. 5

Target Cell (Max)

\begin{tabular}{|l|l|l|l|}
\hline Cell & Name & Original Value & Final Value \\
\hline \$A \$4 & optimal value & 0 & \multicolumn{1}{|c|}{1600} \\
\hline
\end{tabular}

Adjustable Cells

\begin{tabular}{|l|l|l|l|}
\hline Cell & Name & Original Value & Final Value \\
\hline \$B \$4 & Fuel additive & 0 & 25 \\
\hline \$C\$4 & Solvent base & 0 & 20 \\
\hline
\end{tabular}

Constraints

\begin{tabular}{|l|l|r|l|l|r|}
\hline Cell & Name & Cell Value & Formula & Status & \multicolumn{1}{l|}{ Slack } \\
\hline \$D\$5 & material used & 20 & \$D\$5 <= \$E\$5 & Binding & 0 \\
\hline \$D\$6 & material used & 4 & \$D\$6 <= \$E\$6 & Not Binding & 1 \\
\hline \$D\$7 & material used & 21 & \$D\$7 <= \$E\$7 & Binding & 0 \\
\hline
\end{tabular}

Fig. (4): Answer Report

Adjustable Cells

\begin{tabular}{|c|c|c|c|c|c|c|}
\hline Cell & Name & Final Value & $\begin{array}{l}\text { Reduced } \\
\text { Cost }\end{array}$ & \begin{tabular}{|l|} 
Objective \\
Coefficient
\end{tabular} & \begin{tabular}{|l} 
Allowable \\
Increase
\end{tabular} & $\begin{array}{l}\text { Allowable } \\
\text { Decrease }\end{array}$ \\
\hline$\$ B \$ 4$ & Fuel additive & 25 & 0 & 40 & 20 & 16 \\
\hline$\$ C \$ 4$ & Solvent base & 20 & 0 & 30 & 20 & 10 \\
\hline
\end{tabular}

Constraints

\begin{tabular}{|c|l|r|r|r|r|r|}
\hline Cell & \multicolumn{1}{|c|}{ Name } & $\begin{array}{c}\text { Final } \\
\text { Value }\end{array}$ & $\begin{array}{c}\text { Shadow } \\
\text { Price }\end{array}$ & $\begin{array}{c}\text { Constraint } \\
\text { R.H. Side }\end{array}$ & $\begin{array}{c}\text { Allowable } \\
\text { Increase }\end{array}$ & $\begin{array}{c}\text { Allowable } \\
\text { Decrease }\end{array}$ \\
\hline \$D \$5 & material used & 20 & 33.33333333 & 20 & 1.5 & $1 \mathrm{E}+30$ \\
\hline \$D \$6 & material used & 4 & 0 & 5 & $\$ \mathrm{E}+30$ & 1 \\
\hline \$D \$7 & material used & 21 & 44.44444444 & 21 & $\$ \mathrm{E}+30$ & 2.25 \\
\hline
\end{tabular}

Fig. (5): Sensitivity Report 


\section{Conclusion}

Over the last few years the power of spreadsheet has improved dramatically and many decision makers use spreadsheet on a daily basis to provide decision support.

The addition of optimization routines within spreadsheet such as solver in Excel, now provides decision makers with readily available easy to use tools which not only provide decision support assistance for many problems, but also provide post-optimal information which can help enhance decision making effectiveness and focus managerial effort.

Spreadsheet is also a very useful and important tool for solving many other operation research problems such as transportation problems, nonlinear programming problems, dynamic programming problems and queuing problems.

\section{References}

Al-Faraj, Taqui N., et al., (1990), "Simulating the waiting line problem: A spreadsheet application", International Journal of Operations and Production Management, vol. 11 No. 2, pp. 49-53.

Caine, D. J. and Parker; B. J. (1996), "Linear Programming comes of age: a decision support tool for every manager", Management Decision, vol. 34, No.4, pp. 46-53.

Winston, Wayne L. and Aibright, S. Christian (1997), Practical Management Science, Spreadsheet modeling and applications, Wadsworth Publishing Company, New York. 
استخدام الجلداول الإلكترونية لحل نماذج البربحة الخطية

$$
\begin{aligned}
& \text { زلفى عبدالفتاح شلبي } \\
& \text { أستاذ مساعل - قسم إدارة الأعمال } \\
& \text { كلية الاقتصاد والإدارة - قسم الطالبات }
\end{aligned}
$$

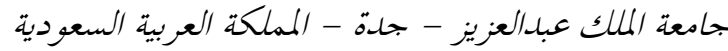

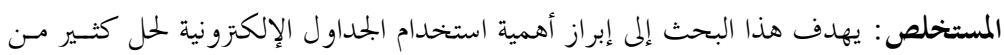

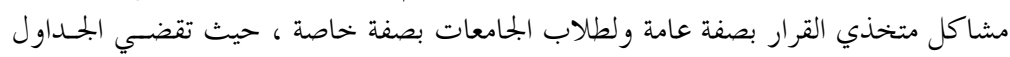

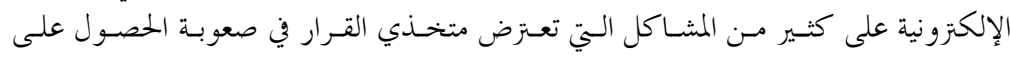

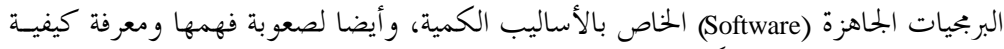

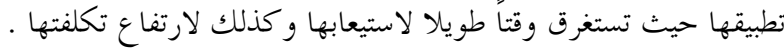

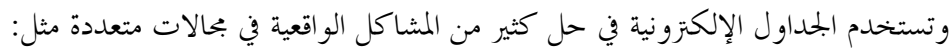

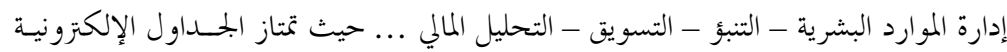

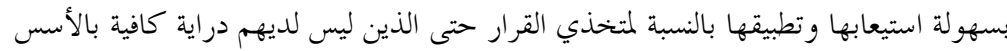

$$
\text { والخلفية الرياضية للأساليب الكمية . }
$$

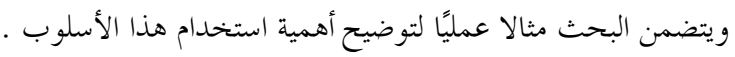

